\title{
Milady Součkovej prywatne archiwum pamięci (na podstawie opowiadania Rok šestašedesátý ze zbioru Neznámý člověk)
}

\begin{abstract}
Woźniak Kamila, Milady Součkovej prywatne archiwum pamięci (na podstawie opowiadania Rok šestašedesátý ze zbioru Neznámý člověk) (Milada Součková's Private Memory Archive [Based on the Short Story Rok šestašedesátý from the Collection Entitled Neznámý člověk]). "Poznańskie Studia Slawistyczne" 19. Poznań 2020. Publishing House of the Poznań Society for the Advancement of the Arts and Sciences, Adam Mickiewicz University, pp. 273-289. ISSN 2084-3011.
\end{abstract}

This article presents an analysis of one of the short stories authored by Czech writer - Milada Součková: the short story Rok šestašedesátý included in the collection entitled Neznámý člověk (published in 1962, written in 1943). The introduction addresses the issues related to the clarification of the concept of a memory archive and the concept of the archive itself. Its characteristics, i.e. a certain arrangement of the collection, its permanent structure and three essential aspects of archiving are indicated: searching, saving and storing. These aspects are also typical of the structure of the analysed prose authored by Milada Součková. The next part of the article (Neznámý člověk as a private archive of memory) pertains to the entire above-metioned volume of the stories whose characteristic motif is the motif of memory linked with space, time and history. In the further parts of the article, the author goes on to the structural and interpretative analysis of the story she is interested in. She draws attention to such aspects as memory figures, i.e. time and space, thematic associations, memory carriers and memory traces and places. In conclusion, she draws attention to three components of the Milada Součková's private memory archive: the memory of the language, the memory of the father and the memory of the historical events taking place in 1866.

Keywords: memory studies; Milada Součková; memory; Czech literature; Czech avant-garde

Formę i naturę istoty ludzkiej, jak i jej egzystencję, określają m.in. dynamizm i porządek różnego rodzaju związków, w których zostały osadzone, również związków z pamięcią - kulturową, społeczną czy autobiograficzną. Łączy się z tym ciągła, podświadoma potrzeba magazynowania błysków przeszłości, które, zapamiętane bądź zapomniane (wyparte), 
kształtują dalsze życie jednostki i jej poczucie tożsamości. Niniejszy szkic dotyczył będzie właśnie owego magazynowania wspomnień i tworzenia pomostów między przeszłością, teraźniejszością a przyszłością.

\section{Archiwum pamięci}

Pamięć uznać można za swoiste repozytorium wiedzy, prywatne, osobiste archiwum. Zgromadzone w nim artefakty stanowią pewien uporządkowany zbiór, „korpus pamięci instytucji, społeczności i jednostki” (Saryusz-Wolska, Traba, 2014, 93). „Relacja między pamięcią a archiwum ma charakter dynamiczny i aporetyczny. Istotą archiwum [...] jest bowiem napięcie między pragnieniem źródłowego powtórzenia i zachowania wydarzenia a jego nieuchronnym zacieraniem i wypieraniem" (Saryusz-Wolska, Traba, 2014, 95). W procesie archiwizacji istotne są trzy aspekty, mianowicie poszukiwanie, zapisanie i przechowywanie (Weinrich, 2018, 319). Podobną rolę odgrywa pamięć, która, jak archiwista, wybiera, selekcjonuje i przechowuje ślady i odciski, jednocześnie je interpretując i przekształcając (często nieświadomie w wyniku upływu czasu). Staje się ona mediatorem w procesach zapamiętywania, wspominania i upamiętniania. Szczególnie pamięć autobiograficzna tworzy swego rodzaju amalgamat składający się ze śladów własnych wspomnień i skryptów informacji z wielu różnych źródeł (Rydiger, 2013, 129). Ten rodzaj pamięci, jak stwierdza Tomasz Maruszewski (2005, 31), występuje w postaci narracji dotyczących ciągów zdarzeń i informacji na temat faktów. Pamięć autobiograficzna staje się więc swego rodzaju prywatnym archiwum jednostki, w którym zawierają się nie tylko wspomnienia związane z jej życiem prywatnym, ale również te, które dotyczą szerszego kontekstu społecznego i kulturowego.

\section{Neznámý člověk jako prywatne archiwum pamięci}

Za takie właśnie prywatne archiwum pamięci można uznać tom opowiadań Neznámý člověk czeskiej pisarki Milady Součkovej (1899-1983). Autorka wspomniany zbiór wydała w roku 1962, a więc podczas swojego 
pobytu w Stanach Zjednoczonych (emigracja). Proza ta powstała jednak dużo wcześniej, mianowicie w roku 1943, i była ostatnim dziełem prozatorskim tej autorki. Tom zawiera jedenaście krótkich opowiadań oraz posłowie w formie listu pisarki do anonimowego adresata, przypuszczalnie Jindřicha Chalupeckiego, z którym Součková przyjaźniła się i który często był pierwszym czytelnikiem jej prac. W posłowiu autorka wspomina o motywie pojawiającym się w każdym z tekstów tego tomu (i w ogóle w całej jej twórczości, tak prozatorskiej, jak i poetyckiej), chodzi o pamięć powiązaną z przestrzenią, czasem i historią ${ }^{1}$. W tym wypadku pamięć o wydarzeniach historycznych konfrontowana jest z pamięcią anonimowego człowieka, który mógł być ich świadkiem. Opowiadania prezentujące te mikro- i makrohistorie ułożone są chronologicznie. Tom otwiera opowiadanie Rok šestašedesátý nawiązujące do bitwy pod Hradcem Králové, a zamyka opis kongresu filozoficznego, który odbył się w Pradze w roku 1934.

Součková w swoim zbiorze opowiadań tworzy narracyjną mapę wydarzeń historycznych, począwszy od końca XIX wieku, kończąc na latach trzydziestych wieku XX. Celem konstruowania tej sieci informacji nie jest, jakby się mogło wydawać, rekonstrukcja historyczna, lecz raczej szukanie powiązań między konkretnymi wydarzeniami a ich świadkami - tytułowymi nieznanymi ludźmi. Wielowarstwowość przywoływanych epizodów układa się w palimpsest pamięci i jest znakiem rozpoznawczym całej twórczości tej autorki. Warstwy czasowe poszczególnych narracji, przeszłość i przyszłość, nakładają się na siebie, wspomnienia narratora mapują rzeczywistość i przekształcają ją w narrację pamięci. To archiwum, w którego skład wchodzą przypomniane i zapisane zdarzenia, zawiera w sobie nie tylko narracje prywatne i autobiograficzne, ale też przytoczenia wypowiedzi ludzi świata polityki, fragmenty nagłówków z ówczesnych gazet i prywatnych rozmów polityków. Taki sposób budowania świata przedstawionego, jego polifonia, liczne obcojęzyczne cytaty, wszystko to pogłębia kontrast między światem powszednim, a światem wielkiej polityki i wielkiej historii. Widać to doskonale m.in. w pierwszym opowiadaniu, którego dotyczyć będzie niniejszy szkic analityczny.

${ }^{1}$ Co ciekawe, w jednym z listów do Chalupeckiego Součková odnotowuje coś wręcz odwrotnego: „Nemám ráda konfrontace s minulostí, patří do poezie a do zpytování svědomí” (Součková, 2018, 109). 


\section{Rok šestašedesátý - figury pamięci (czas i przestrzeń)}

Paul Connerton pisze, że „opowieść, jaką tworzy czyjeś życie, jest częścią zespołu łączących się między sobą opowieści. Jest ona zawsze osadzona w historii tych grup, z których wyłania się tożsamość jednostki" (Connerton, 2012, 63). Ta tożsamość budowana jest poprzez poczucie przynależności do kręgu opowieści własnych i cudzych. Pamięć przyswaja te opowieści, zapisuje, magazynuje, często dekontekstualizuje i tworzy $\mathrm{z}$ nich nową strukturę. W tym prywatnym archiwum zachowane zostaje to, co „narusza zwyczajową monotonię, odbiega od rutyny, łamie ciągłość, zaskakuje, dziwi” (Pomian, 2006, 145). Jak stwierdza Aleida Assmann, człowiek zawsze definiuje się poprzez te więzi i przynależność do innych i to właśnie subiektywne doświadczenie jednostki, wpisane w kręgi pamięci rodziny, pokolenia, społeczeństwa czy kultury, jest punktem wyjścia dla różnych form narracji memoralnych (Assmann, 2013, 11, 40). Owe narracje zawierają w sobie akty pamięci, których przedmiotem jest historia życia danej jednostki splatająca w sobie nie tylko motywy biograficzne, ale też wspomnienia innych.

Każde wspomnienie, jakkolwiek osobisty miałoby charakter [...] istnieje w odniesieniu do całego zespołu spostrzeżeń, które posiada wielu innych ludzi: do osób, miejsc, dat, form języka, a więc w odniesieniu do całego materialnego i moralnego życia społeczeństw, których [jednostka - uzupeł. tłumacza] stanowi lub stanowiła część (Connerton, 2012, 87).

Podmiot wszystkie te doświadczenia i wspomnienia magazynuje W swojej pamięci, tworząc ustrukturyzowaną sieć narracji.

W opowiadaniu Rok šestašedesátý taką właśnie archiwizującą strukturę narracyjną tworzą dwa łączące się wątki tematyczne: tytułowy związany z bitwą z roku $1866^{2}$ oraz wspomnień o ojcu narratora. Oba biegną równolegle, mając wiele punktów stycznych. Součková komponuje swój tekst w bardzo przemyślany sposób, jedna reminiscencja wywołuje kolejną, tworząc łańcuchy asocjacji.

Punktem odniesienia dla pamięci jest tu niewątpliwie, jak w całym tomie, wielka i mała historia. Součková, zestawiając wydarzenia historyczne

${ }^{2}$ Bitwa pod Sadową miała miejsce 3 lipca 1866 roku i była częścią wojny Prusko-Austriackiej. 
z wydarzeniami autobiograficznymi (męskiego narratora można uznać za alter ego pisarki), te pierwsze przedstawia neutralnie, nie ustosunkowuje się w żaden sposób do faktów związanych z samą bitwą, co przypomina „suchy” opis encyklopedyczny, zwłaszcza gdy narrator podaje dane dotyczące np. liczebności armii Bismarcka czy pozycji zajmowanych przez jego wojska, a cytowane wypowiedzi generałów i fragmenty artykułów z gazet drukowane są kursywą, by uwiarygodnić przekaz i odróżnić je od partii biograficznych. Opis planu osobistego ma natomiast charakter wręcz kronikarski, lekko zabarwiony emocjonalnie, np.:

Zatím začaly oddíly Friedricha Karla a Herwarthovy pochodovat. Bylo ošklivé ráno. Po vedru předešlých dní pršelo. Vojsko se prodíralo mokrým obilím a po rozmoklých cestách. 3. července 1866. Deštivé ráno po horkém krásném dni (Součková, 1995, 14).

oraz:

Král Vilém osobně domlouval prchajícím důstojníkům. Vyřkl slovo: Auerstedt. V jeho družině bylo vidět vážné obličeje. I Bismarckovo čelo nebylo bez chmur. Moltke zachovával klid, a když se ho král ptal, co zamýšlí v př́ípadě ústupu, řekl: Hier handelt Ed sich um die Zukunft Preussens. Hier wird nich zurückgegangen. Věděl, že ho korunní Prince nezklame, jako nezklamal Blücher Wellingtona u Waterloo (Součková, 1995, 16).

Zestawienie oficjalnych wtrętów z wpisami o charakterze prywatnym, unaocznia w tekście pewną strukturę pamięci kolektywnej. Można tu mówić o swoistej polityce historycznej, za którą uważa się każde opowiadanie, dyskurs czy interpretację przeszłości tworzoną przez instytucje władzy (Maslowski, 2014, 71). Zabieg ten pozwala Součkovej uwypuklić kompozycję opowiadania (i całego tomu), którego celem jest właśnie zestawienie wspomnień prywatnych i oficjalnych.

Inaczej skonstruowana jest charakterystyka postaci ojca. Tu widoczny jest silny rys emocjonalny, nacechowany subiektywną deskrypcją wydarzeń z jego życia i jego wspomnień o roku 1866. Takie zróżnicowanie w stylu opisów akcentuje opozycję kategorii podmiotowości i uniwersalności reprezetujących pamięć i historię. Do tej pierwszej należą teksty opowieści wspomnieniowych, które cechują się rekonstruktywnością rodzinno-osobistą. Marta Wójcicka w swojej monografii poświęconej pamięci zbiorowej w tekstach oralnych konstatuje: 
[p]rzedmiotem rekonstruktywności są wydarzenia z dzieciństwa lub młodości narratora, wpisane w znaczące dla rodziny, okolicy lub ojczyzny wydarzenia historyczne. Nie wielka historia jest tu jednak przedmiotem opowieści, a pojedyncze lub przywołane sekwencyjnie opowieści z różnych względów zapamiętane (Wójcicka, 2014, 245).

W omawianym utworze rekonstruktywność, wiążąca się dokładnie z tym, o czym mówi badaczka w przytoczonym cytacie, jest złożona i odbywa się na kilku płaszczyznach czasowych i wspomnieniowych, mianowicie:

- narrator wspomina swoje dzieciństwo,

- narrator wspomina ojca,

- narrator wspomina (i przytacza) opowieści ojca o jego dzieciństwie i bitwie pod Hradcem Králové,

- narrator przypomina sobie neutralne fakty związane z samą bitwą.

Wspomnienia narratora odnoszą się do sytuacji, w których uczestniczył osobiście, natomiast impersonalna forma odtworzenia zdarzeń, w których nie brał udziału (bitwa) jest przywołaniem faktów (Saryusz-Wolska, Traba, 2014, 1491) zawartych w opowieściach ojca. Kategoria czasu, która wspiera pamięć, jednocześnie będąc jej nośnikiem (Wójcicka, 2014, 201) w omawianym opowiadaniu, determinuje linie tematyczne. Czasowi historycznemu pisarka przeciwstawia „czas chwil i doświadczeń życiowych o różnej intensywności”, który można nazwać mikroczasem (Bal, 2009, 80) łączącym się z pamięcią retrospektywną. Owa pamięć momentami przechodzi w pamięć prospektywną odnoszącą się do przyszłości:

Náš otec asi nevěděl, ačkoliv jako dospělý člověk měl předplacený Národní listy, že válka roku 1866 byla vykládána jako uplatnění národnostní zásady. Ale již od dětství znal slova: Bismarck, železný kanclér. Jako dospělý člověk ovšem věděl o Bismarckovi více (Součková, 1995, 13).

Przechodzenie z jednej perspektywy czasowej do drugiej podkreśla poczucie doświadczania przeszłości, tworzenia krajobrazu pamięci, w centrum którego stoi ojciec narratora, jako świadek historii, ,żywe archiwum". Odpowiadają temu słowa Henriego Bergsona, który twierdzi, iż „trwanie nie polega [...] na tym, że jedna chwila zastępuje inną; istniałaby bowiem wtedy tylko teraźniejszość [...]. Trwanie to ciągłe postępowanie przeszłości, wgryzającej się w przyszłość i nabrzmiewającej w miarę postępowania naprzód" (Bergson, 1988, 40). 
Lucie Machová w artykule zatytułowanym Pamięć konstatuje, że dzieło sztuki, które zawiera w sobie obrazy przeszłości, obdarzone jest wartością odróżniającą je od pozostałych dzieł. Tą wartością jest jego czasowa i przestrzenna wieloznaczność (Machová, 2015, 22), która uobecnia się również $\mathrm{w}$ analizowanym tekście. Wieloznaczność przestrzenną budują m.in. elementy pamięci asocjacyjnej.

Narrator uruchamia łańcuch tego rodzaju skojarzeń w dwóch sytuacjach, o których wspomina na początku oraz na końcu opowiadania. Opisywane bodźce oddziałują na niego w jego teraźniejszości, odsyłając do zdarzeń minionych. Jan Kordys $(2001,141)$ pisze o takim zjawisku jako o paradoksie pamięci: „Ciągłe odtwarzanie przeszłości możliwe jest tylko w odniesieniu do chwili obecnej, lecz to właśnie przeszłość kieruje naszą percepcją teraźniejszości i konstrukcją przyszłości”. Badacz zauważa też, że początkowo nieoczekiwane, spontaniczne i nieświadome reminiscencje przechodzą w świadomą rekonstrukcję opartą na doborze i selekcji:

w tym procesie pamięć, narracja i świadomość łączą się ze sobą. Odnosimy wtedy wrażenie, że wspominanie jest tożsame z odtwarzaniem i opiera się na przywoływaniu „czegoś”, co zostało „kiedyś” utrwalone, dając poczucie momentalnej realności i jest to właśnie ta chwila, gdy łączą się ze sobą dwa porządki: reminiscencja czy nagle wyłaniające się wrażenia wpisują się w ciągłość historii (Kordys, 2001, 138).

Takie dwa nieświadome momenty „odtwarzania”, dające początek późniejszemu świadomemu przywracaniu przeszłości, wiążą się w opowiadaniu Součkovej z przestrzenią.

Narrator aktywuje łańcuch asocjacji i wspomnień w związku z dwoma miejscami. Pierwszy bodziec daje mu przestrzeń otwarta - natura i przyroda. Zmysły uruchamiają pamięć zawsze wtedy, kiedy wędruje łąkami i polami w swoich rodzinnych stronach (Součková, 1995, 8), drugim impulsem, o którym wspomina na końcu opowiadania, jest wizyta w muzeum (przestrzeń zamknięta) i oglądany obraz, który przypomina mu to, o czym opowiadał ojciec (Součková, 1995, 19). Całą przestrzeń pamięci kształtują w tym tekście ślady o charakterze memoratywnym. Należą do nich m.in. konkretne, wymieniane przez narratora, a wspominane przez ojca, miejscowości (Hradec Králové, Jičín, Sadová, Chlum, Ovčák, Javůrek) mające związek z bitwą, a także lokalizacje wojsk pruskich łączące się z pojawiającymi się w opowiadaniu niemieckimi cytatami - te są 
drugorzędne, jednak powiązane z kontekstem historycznym. Ramą narracji wspomnieniowej jest również przestrzeń intymna tworzona przez obrazy domu, w którym ojciec spędził dzieciństwo, i okolicy (często powtarza się intymistyczny wątek pól, łąk, lasów, strumieni i rzek). W tym przypadku można mówić o nostalgicznej konceptualizacji przestrzeni. Nostalgiczne ,ja" narratora tęskni nie tylko za miejscem utraconym, ale też, a może przede wszystkim, za „sobą dawnym w tym miejscu”, za swoją młodością, dzieciństwem i ojcem, za czasem utraconym (Zaleski, 2004, 16). „Estetyka nostalgii jest [więc tu - K.W.] zmącona: to piękno, które rodzi [w narratorze - K.W.] melancholię, przyjemność, która sprawia ból" (Zaleski, 2004, 12). Odwołując się do słów Svetlany Boym, można powiedzieć, że mamy tu do czynienia z tzw. nostalgią restauratywną, czyli tęsknotą za tym, co było, za pochodzeniem, prawdą oraz utraconym „domem” (za: Erll, 2018, 90). Rzeczywistość wyobrażona i rzeczywistość doznana stapiają się w narrację pamięci o nacechowaniu nostalgicznym.

Częścią tej wspomnieniowej struktury, stelażem, na którym opiera się cała fabuła, jest wspomniany wcześniej łańcuch asocjacji. Pojawiają się w nim naprzemiennie wydarzenia oficjalne (historyczne) i prywatne wspomnienia ojca i narratora. Jedna reminiscencja danego przedmiotu, słów piosenki czy wydarzenia łączy się z kolejną, przywodzi na myśl przeżycia z dzieciństwa, po czym powraca kontekst polityczno-historyczny. Przypomina to strumień świadomości, w którym, pod wpływem chwilowego przeżycia, narrator daje się unieść swej pamięci.

Takie obrazowanie przestrzeni, w połączeniu z opisaną konstrukcją czasu (a więc specyficznym połączeniem przeszłości, teraźniejszości i przyszłości) sprawia, że omawiany utwór przyjmuje znamiona opowieści mitycznej, w której bohater powraca do czasów dzieciństwa, aby odnaleźć tam swoje ,ja”. Postawa intymistyczna narratora sprzyja budowaniu przekazu o świecie minionym, o legendarnej, utraconej prywatnej ojczyźnie. Marek Zaleski pisze o rzeczywistości mitycznej i jej powiązaniu z formami pamięci następująco:

Pod powierzchnią faktów i zdarzeń historii, jaką odtwarza instrumentalnie ukierunkowana pamięć, skrywa się inna historia: pozornie błaha, subiektywna bądź mało istotna z punktu widzenia historyka, ale równie przecież rzeczywista. Pod piórem pisarza nabiera znamion rzeczywistości mitycznej. Mityzacji ulega [...] sama czynność wspominania, zmieniając się w rytuał ocalania od zapomnienia, wydobywania pamięci z prze- 
paści niepamięci, wyzwolenia przeszłości. Powracający w przeszłość, która zawsze istnieje niejednoznacznie i pod niejasną postacią, przypomina mitycznego bohatera: podejmuje wyprawę w głąb labiryntu, za jedyne wsparcie mając wątłą i niepewną nić pamięci (Zaleski, 2004, 28).

Ów mityczny bohater, o którym wspomina Zaleski, to ojciec narratora, ale i sam narrator, próbujący „ocalić od zapomnienia” świat dzieciństwa własny i ojca. Mityczna przeszłość przyjmuje w opowiadaniu wiele form, od nostalgicznych wspomnień, po odwołania do wydarzeń historycznych. Mamy tu do czynienia również z pewnym paradoksem opowieści o genezie: rozpoczyna się ona w momencie, kiedy już wszystko się dokonało (Augé, 2009, 74) i to, co opowieść przedstawia, nabiera sensu dopiero w teraźniejszości narratora.

\section{Nośniki pamięci}

Marcin Kula odnotowuje, że ,przeszłość odzwierciedla się [...] w każdym przedmiocie i zjawisku, które trwa do dziś. W konsekwencji [...] nośnikiem pamięci [...] jest dosłownie wszystko" (Kula, 2002, 7). W opowiadaniu Rok šestašedesátý nadrzędnymi nośnikami pamięci są: język oraz postać ojca.

Ojciec narratora ożywia historię. To w jego opowieściach i w języku, w którym są one zamknięte, zarchiwizowana jest cała wiedza o przeszłości, o jego dzieciństwie, o wydarzeniach roku 1866. Język buduje w tym tekście czasową przestrzenność wypowiedzi, odsyła do roku 1866, ale i do czasów współczesnych narratorowi opowiadania, np.: „U silnice, kudy šla vojska za života našeho otce: roku 1866; roku 1914 tudy narukovali a roku 1942 již nebyl náš otec naživu" (Součková, 1995, 8). Konkretyzacja staje się dalej jeszcze bardziej szczegółowa i kieruje do określonych godzin i miejsc, zestawia wydarzenia odgrywające się w różnych płaszczyznach czasowych, ale o tej samej godzinie:

Náš otec byl již mrtev a za stolem seděl jeho nejstarší bratr, jeho svobodný syn a dcera. [...] Nepoznal nás, až když jsme řekli, kdo jsme; pak výkřikl a sestřenka začala snášet na stůl pod větrným mlýnem: buchty, kávu a odnášet talíre, kastroly po bramborách a smažených řízcích - byla neděle. Na hodinách bylo tři hodiny a čtyřicet minut. Roku 
1866, ve tři hodiny a čtyřicet minut, bylo vidět z chlumů a výšin ustupující rakouskou pěchotu. Větrné mlýny na Chlumu a Ovčáku se točily (Součková, 1995, 17).

Język, jako nośnik, „kształtuje pamięć w samej jej treści, bo nastawia i ukierunkowuje postrzeganie oraz wpływa na zatrzymywanie danych. [...] pozwala jednostce przede wszystkim gromadzić opowieści przodków [...] i zachowywać je w pamięci” (Pomian, 2006, 146). Cała wiedza o przeszłym świecie, o życiu, rodzinie narratora jest zachowywana w opowieściach ojca, kształtując tym samym nie tylko pamięć autobiograficzną, ale też semantyczną (cf. Součková, 1995, 14), komunikacyjną (,wyobrażenia o przeszłości przekazywane z pokolenia na pokolenie, przeważnie w obrębie rodziny" [Saryusz-Wolska, Traba, 2014, 942]) i kulturową. Tę ostatnią, według Andrzeja Szpocińskiego, można scharakteryzować jako coś, „co pozostaje z przeszłości w przeżyciach członków grupy [...] - zbiór wspomnień o zdarzeniach (rzeczywistych lub zmyślonych) przeżytych bezpośrednio lub takich, o których wiedza przekazywana jest z pokolenia na pokolenie w tradycji ustnej” (za: Wójcicka, 2014, 37). Przykładem pamięci zbiorowej są w tekście Součkovej m.in. słowa piosenki, które narrator przywołuje w opowiadaniu kilkakrotnie, np.:

Kdo není z našeho, anebo alespoň nám blízkého pokolení, nebude asi nic, nebo jen málo vědět o válce roku šestašedesátého. Skoro každý z nás však zná tu písničku: U Královýho Hradce, lítaly tam koule prudce! Skoro každý zná tu písničku. Známe ji od našeho otce. Kdo by ji neznal! [...] Každé dítě vám o tom zazpívá písničku! Každé dítě u nás, co říkám: každé dítě v Čechách: U Královýho Hradce, litaly tam koule prudce z kanonů a flintiček (Součková, 1995, 8, 18).

Jej tekst, który można też uznać za ślad pamięci wskazujący na symboliczne trwanie nieobecnego, niesie ze sobą podwójne kodowanie, zapis pamięci nie-swojej, nabytej z drugiej ręki. Narrator wspomina: „Slýším ji, tu lidovou písníčku světové historie. Náš otec ji pamatuje a my ji známe od něho" (Součková, 1995, 8, cf. też 10). W tych słowach, w języku, jest zapisane właśnie to, o czym pisał cytowany już Szpociński - zapisane są wspomnienia wydarzeń przekazywane z pokolenia na pokolenie w tradycji oralnej. Tekst piosenki staje się w opowiadaniu swego rodzaju leitmotivem podkreślającym wagę wydarzeń, ale i potwierdzającym siłę pamięci kulturowej i pamięci języka. Podobną funkcję pełni przytaczany kilkakrotnie przez narratora zwrot „psí dní” (,psie dni“), również mający związek 
z rokiem 1866, choć nie tylko. Zwrot ten ma w tekście potrójną konotację. Starożytni Rzymianie określali tym mianem okres, kiedy na niebie pojawiał się gwiazdozbiór Wielkiego Psa, co zapowiadało ogromne upały, drugie znaczenie w tekście wiąże się z początkiem wakacji, a trzecie niesie ze sobą negatywny wydźwięk związany z bitwą. Opowiadania ojca łączą w sobie te trzy sensy, przywołują je w kontekście wydarzeń wojennych (cf. Součková, 1995, 12). Owe przywołania mogą też jednak wskazywać na pewną tendencyjność pamięci - zniekształcenia, którym poddaje ona przeszłe obrazy, jak również kontrfaktyczny sposób myślenia, czyli generujący scenariusze tego, co mogło się wydarzyć (ale nie musiało!). Narrator wielokrotnie w tekście wspomina, że czegoś nie widział lub kogoś nie znał osobiście, a jednak wie, że tak było za sprawą opowieści ojca (cf. Součková, 1995, 10). Tego rodzaju wspomnienia, oparte na myśleniu kontrfaktycznym, są jednym z siedmiu grzechów pamięci, o których pisze Daniel L. Schacter. Mowa tu o grzechu podatności na sugestie, który oznacza tendencję jednostki do włączania mylącej informacji z innych źródeł, pochodzącej od innych ludzi, z gazet lub zdjęć (Schacter, 2003, 173; cf. Součková, 1995, 12-13).

We wspomnieniach narratora o ojcu zawiera się cały kunszt budowy utworu. Součková tworzy tekst, w którym pamięć układa się szkatułkowo, czy może lepiej - kaskadowo (w odróżnieniu od budowy szkatułkowej, w układzie kaskadowym każdy element tekstu jest równie ważny i na tym samym poziomie narracyjnym, co poprzednie). Progami pamięci, które determinują dalszy bieg tekstu, stają się przełomowe wydarzenia historii powszechnej, ale i (a może przede wszystkim) wydarzenia $\mathrm{z}$ historii rodziny narratora. Poziomy narracji przeplatają się i stapiają (Bal, 2012, 52). Ta skomplikowana kompozycja tekstu, w którym każdy kolejny akapit jest nowym ogniwem łańcucha asocjacji, podkreśla sam proces pamiętania, zapamiętywania i odtwarzania. Celem takiego prowadzenia narracji jest zaakcentowanie jego konkretnego typu, czyli zapisu strumienia świadomości. I to właśnie język staje się narzędziem owego umysłowego i zmysłowego odtwarzania, archiwizowania całej wiedzy o mikro- i makroświecie. Ojciec staje się w tekście logosem, ludowym opowiadaczem, tworzącym i utrzymującym wspólnotę pamięci. Jego opowieści kreują rzeczywistość narratora, wpływają na jego wiedzę o przeszłości rodziny i przeszłości kraju. $\mathrm{W}$ pewnym stopniu opowieści ojca są również nacechowane emocjonalnie 
(w odróżnieniu od wypowiedzi samego narratora), nazywają i wartościują doświadczenia, stanowią rekonstrukcję rzeczywistości dawno minionej (Czachur, 2016, 255), której ślady przechodzą do szerszej pamięci społecznej:

Vidíme před sebou celou krajinu, s každou nejmenší podrobností: se zlatou lilií v zahrádce, s kostelíkem na Kopečku, kde odpočívají otcovi rodiče, naši prarodiče. Neznali jsme je; při otcových slovech však stačí zavříti oči a vidíme jeho matku, celou utrápenou těmi třemi kluky a jejich klukovinami [...]. Neznali jsme rodiče našeho otce, ale vidíme je před sebou, slyšíme ty pradědový skřípky, jak hrají v hospodě skočnou (Součková, 1995, 10).

Jak často jsme slýchali našeho otce vyslovovat: Sadová! Slovo plné letní pohody; v sadech dozrávají třešně. Sadová! Slovo, jež měl náš otec tak rád, mohlo být místem hrůzy a smrti? To nebyl sad, jehož švestky byly ukryty ve studni z červených cihel [...] Sady, studně, sýpky, ploty a vše, co tak rád vyprávěl náš otec, se stalo náhle dějištěm historických události. Náš otec je na to pyšný, když nám to vypráví: Sadová! Slova, s nimiž si hrával jako dítě, se dostávají do úst lidí, kteří našeho otce neznali (Součková, 1995, 15).

Vyslovuje-li náš otec jméno Benedek, slyšíme tam již jen ozvěnu té slávy získané na italských bojištích, jen ohlas toho posměšku tomu, kdo sotva věděl, kde teče Labe, v jehož mrtvých ramenech náš otec jako kluk lovil lekníny (Součková, 1995, 18).

Przytaczane przez narratora opowieści ojca często zawierają testymonialne wyrażenia formuliczne wskazujące na obieg tekstu w przekazie ustnym, międzypokoleniowym, pełnią one funkcję komunikacyjną w kształtowaniu pamięci społecznej (Wójcicka, 2014, 132). Te wyrażenia podkreślają wartość wspomnień dla samego narratora, ale też odnoszą się do języka i mowy jako nośników pamięci, są to zwroty i zdania typu: „Když náš otec vyslovuje ta jména”, „Náš otec o tom vypravuje”, „Náš otec to vyslovuje ve zpěvné melodii, snad proto, že má rád slova, snad proto je vyslovuje zdrobněle, snad proto je zpívá" (Součková, 1995, 9, 17).

W całym tekście wyczuwalna jest nostalgia za światem i czasem utraconym, tym, co na zawsze przeminęło. Wyczuwalna jest również miłość do mowy ojczystej, do jej odmian, narzeczy i brzmienia. W tym wypadku to znów postać ojca jest tą, która chroni w sobie tę mowę, zachowuje to, co najważniejsze, co buduje tożsamość narratora. Ten w każdym prawie akapicie podkreśla to umiłowanie ojca do języka, który w słowach i brzmieniu ujmuje wspomnienia, wskrzesza i kreuje dawne światy i zachowuje to, co mogłoby zostać zapomniane: 
Jak obdivuhodnou pamět' pro čísla měl náš otec! Obdivuhodnou pamět' pro slova, jež jediná mohou uchovat dávno minulé př́iběhy! (Součková, 1995, 11).

O tom všem náš otec již nevypravuje. V jeho hře se slovy žijí dávné dny, dávno minulé deštivé dny po dusných vedrech, kdy cesty byly rozmoklé [...]. Dávno minulý 3. červenec 1866 . Ve slovech našeho otce vidíme naposledy historický obraz [...]. Vždy při tom vzpomenu na našeho otce, na slova jeho rodného kraje, s nimiž si tak rád pohrává, vidím tu radost v jeho očích (Součková, 1995, 19).

Narrator podkreśla też fakt, że każdy język ma swoją własną pamięć, tworzy inne obrazy, inne rzeczywistości. Archiwizuje inne wydarzenia, wspomnienia i egzystencje:

Písmeno $g$ patří cizí řeči, telegrafnímu úřadu, telegramu. Je to písmeno zcela jiné paměti, než je otcova. Je to písmeno psaných, tištěných slov, nelze je vidět se zavřenýma očima, nutno je číst a chápat: Bitte Euer Majestät dringend, Frieden zu schliessen. Katastrofe für Armee unvermeidlich (Součková, 1995, 12).

Narrator w tym fragmencie zwraca również uwagę na dwie strony języka: oralną i tekstową. To ta pierwsza należy do narzędzi, za pomocą których można, według narratora, najlepiej wyrażać wspomnienia ${ }^{3}$.

\section{Ceremonie, miejsca, ślady}

Jerzy Bartmiński, nawiązując do koncepcji pamięci zbiorowej, wspomina o paradoksie wzajemnego uzależnienia, który łączy język i kulturę. Pamięć jest częścią kultury, kształtuje ją i determinuje. Jednym z nosicieli pamięci jest język. Poza nim istotne dla zachowania świadectw przeszłości są też miejsca i rytuały.

Omawiany tekst Součkovej tworzy swoiste zestawienie miejsc pamięci budujących poczucie tożsamości narratora. Bez wspomnień z nimi związanych byłby on całkowicie wykorzeniony i wyobcowany. Są to opisane już wcześniej konkretne miejscowości mające związek z wydarzeniami

${ }^{3}$ Dodać należy, że język jako nośnik pamięci stanowi jeden z istotnych motywów w twórczości Milady Součkovej. Pojawia się np. w tekście Kaladý, aneb, útočiště řčci z 1938 roku i w jej poezji. We wspomnianym tomie opowiadań wątek ten występuje w jeszcze jednym utworze, chodzi o tekst $Z$ neznámého deníku, w którym narrator stwierdza: „Avšak historické události nepotřebují vlastně záznamů, aby žily. Lidé si je pamatují. Podoba měsíce určité noci zajde nanávratně, neuzavřeme-li ji do skřínky slov" (Součková, 1995, 85). 
wojennymi oraz miejsca pamięci prywatnej, indywidualnej, ściśle wiążące się z dzieciństwem ojca - dom rodzinny, jego okolice, ogrody, sady, pola, stawy, łąki itd. Pamięć codziennego życia wpisuje się w pamięć krainy, w której wychował się ojciec i narrator, a ta w szerszy kontekst pamięci miejsca (Maur, 20014, 145). Miejsca pamięci pojawiające się w analizowanym opowiadaniu przybierają trzy wymiary i, zgodnie z tym, co przedstawił Pierre Nora, można je podzielić na mające wymiar materialny (w opowiadaniu związane są z wydarzeniami historycznymi), funkcjonalny (pomnik poległych) i symboliczny (składanie wianków pod pomnikiem) (za: Erll, 2018, 47).

Śladem, ale i odciskiem pamięci, jest wspomniany pomnik, który upamiętnia poległych w walce roku 1866. Součková pisze o nim już w pierwszych linijkach tekstu ${ }^{4}$. Opis pomnika łączy się z pierwszym wspomnieniem słów śpiewanej piosenki:

slyším ji, tu písničku [...]; když vyjdu na silnici, kde stojí pomník padlým roku 1866; jejich jména jsou vypsána na pomníku, ale kdo z nás je zná? Některá již zmizela a stala se neznamá. Slyším ji, tu lidovou písničku světové historie. [...] Naše sestřenka ji zpívá; zpívala mi ji, když vinula z kvítí věneček a pověsila jej na pomník padlým roku 1866. Hradec Králové 52 km. Zde v Pánu odpočívá 67 pruských a 76 rakouských vojínů (Součková, 1995, 8).

W tym fragmencie narrator przywołuje ceremonię upamiętniania (wianki). Paul Connerton podkreśla, że doświadczanie teraźniejszości ma ścisły związek z wiedzą o przeszłości. Pisze, że doświadczamy naszego teraźniejszego świata w kontekście, który jest przyczynowo związany z przeszłymi wydarzeniami (Connerton, 2012, 33), a więc te różnego rodzaju ceremonie upamiętniania, wchodzące w ramy pamięci społecznej, stanowią swego rodzaju archiwizujące praktyki zapisu i przechowywania. Powyższy cytat z opowiadania czeskiej autorki zawiera również inny istotny element. Mimo iż na pomniku widnieją wyryte nazwiska poległych, to niektóre z nich już wyblakły, zatarły się w świadomości i pamięci ludzi. Dla tych poległych czas okazał się bezwzględny, a praktyki upamiętniania niewystarczające. To może odnosić się do drugiego, bardziej subtelnego i ukrytego znaczenia tytułu całego tomu - nieznany człowiek to też

${ }^{4}$ Pomnik jako ślad i odcisk pamięci pojawia się w wielu innych utworach tej pisarki, np. w tekście Hlava umělce: studie k větši práci z 1946 roku. 
ten, który był nie tylko świadkiem, ale i ofiarą historii, o którym już się nie pamięta. „Zapomnienie [...] również ma swoje znaczenie dla miejsca i obecnych w nim śladów przeszłości”, stwierdza Małgorzata Czermińska (2015, 146). Natomiast Marc Augé $(2009,21)$ konstatuje, że zapomnienie, poza wymiarem negatywnym - obojętnością i niedbałością, wyraża też przebaczenie, oderwanie się od przeszłości i dalsze życie. Pokrewieństwo pamięci i zapomnienia jest więc, według niego, niepodważalne, a „sama pamięć też potrzebuje zapomnienia: trzeba stracić najbliższą przeszłość, by odnaleźć przeszłość najdawniejszą" (Augé, 2009, 13). Do tego, zdaje się, dąży narrator opowiadania Součkovej.

Śladów przeszłości jest w analizowanym tekście równie wiele, jak miejsc pamięci. To metaforyczne trwanie przeszłości objawia się w języ$\mathrm{ku}, \mathrm{w}$ ceremoniach upamiętniania, w przyrodzie, w postaci ojca, ale i narratora, który jest symbolicznie naznaczony historią, a poprzez opowieści i wspomnienia staje się jej integralną częścią.

\section{Zakończenie}

Celem niniejszego artykułu była analiza opowiadania czeskiej pisarki Milady Součkovej pod kątem zagadnienia archiwum pamięci i praktyk upamiętniających. To prywatne archiwum, którego literackie artefakty zawiera fabuła opowiadania Rok šestašedesátý, składa się z trzech podstawowych zbiorów pamięci: zapisów dotyczących bitwy, która rozegrała się w roku 1866, zapisu wspomnień o ojcu oraz zapisu o pamięci języka. Tekst Součkovej jest odzwierciedleniem kształtowania się nie tylko pamięci indywidualnej, ale i pamięci zbiorowej w kontekście uwarunkowań historycznych i kulturowych. Przestrzenie magazynowania, zbierania czy kolekcjonowania wiedzy $\mathrm{w}$ analizowanym tekście funkcjonują $\mathrm{w}$ przeszłości, ale są też ściśle sprzężone z teraźniejszością narratora i jednocześnie autorki utworu. Pisarka od początku podkreśla, jak ważny był dla niej, dla jej rodziny, dla Czechów tytułowy rok 1866. O jego istotności dla tego narodu świadczy też odpowiednio dobrane motto, w którym m.in. zacytowane zostały fragmenty z utworów Josefa Svatopluka Machara (z wiersza pt. Padlým u Sadové) i wspomnień Aloisa Jiráska ( $Z$ mých pamétí). Analizowane opowiadanie różni się od pozostałych tekstów zawartych 
w zbiorze Neznámý člověk przede wszystkim kunsztowną, złożoną kompozycją oraz retoryką pamięci. Jest to tekst, w którym język wyraża, interpretuje i modeluje pamięć (Wójcicka, 2018, 71), natomiast postać ojca staje się swego rodzaju mediatorem. Prywatne archiwum pamięci Milady Součkovej, wzniesione na kartach analizowanego opowiadania, zawiera w sobie zapis doświadczania przeszłości, refleksje o charakterze nierzadko historiozoficznym, a w pewnym momencie staje się też archiwum pamięci kulturowej. Jest afirmacją przeszłości, metanarracją upamiętniającą, a przede wszystkim świadectwem czasu, który przeminął.

\section{Literatura}

Assmann, A. (2013). Między historiq a pamięcią. Antologia. Red. M. Saryusz-Wolska. Warszawa: Wydawnictwa Uniwersytetu Warszawskiego. https://doi.org/10.31338/ uw.9788323514497.

Augé, M. (2009). Formy zapomnienia. Przeł. A. Turczyn. Kraków: Towarzystwo Autorów i Wydawców Prac Naukowych Universitas.

Bal, M. (2012). Narratologia. Wprowadzenie do teorii narracji. Przeł. zespół thumaczy Instytutu Filologii Polskiej UAM w Poznaniu. Kraków: Wydawnictwo Uniwersytetu Jagiellońskiego.

Bergson, H. (1988). Pamięć i życie. Przeł. A. Szczepańska. Warszawa: Instytut Wydawniczy Pax.

Connerton, P. (2012). Jak spoteczeństwa pamiętaja. Przeł. M. Napiórkowski. Warszawa: Wydawnictwo Uniwersytetu Warszawskiego. https://doi.org/10.31338/ uw.9788323520023.

Czachur, W. (2016). Dlaczego pamięć społeczna może być obiektem badań lingwistycznych? W: Karly na ramionach olbrzymów. Kultura niemieckiego obszaru językowego dialogu z tradycja, t. 2. Red. J. Godlewicz-Adamiec, P. Kociumbas, E. Michta. Warszawa: Instytut Germanistyki Uniwersytetu Warszawskiego, s. 252-260.

Czermińska, M. (2015). Tożsamość ksztattowana w pamięci miejsca. W: Kulturowa historia literatury. Red. A. Łebkowska, W. Bolecki. Warszawa: Instytut Badań Literackich PAN, s. 145-160.

Erll, A. (2018). Kultura pamięci. Wprowadzenie. Przeł. A. Teperek. Warszawa: Wydawnictwo Uniwersytetu Warszawskiego. https://doi.org/10.31338/uw.9788323534174.

Kordys, J. (2001). Pamięć i opowiadanie. W: Praktyki opowiadania. Red. B. Owczarek, Z. Mitosek, W. Grajewski. Kraków: Universitas, s. 127-173.

Kula, M. (2002). Nośniki pamięci historycznej. Warszawa: Wydawnictwo DiG.

Machová, L. (2015). Pamět. W: Tektonika paměti. Red. L. Machová, T. Petišková, A. Vartecká. Brno: Dům umění města Brna, s. 18-30. 
Maruszewski, T. (2005). Pamięć autobiograficzna. Gdańsk: Gdańskie Wydawnictwo Psychologiczne.

Maslowski, N. (2014). Politika paměti jako nástroj manipulace a morálky. W: Kolektivni pamět'. Red. N. Maslowski, J. Šubrt. Praha: Karolinum, s. 69-81.

Maur, E. (2014). Památná místa: Místa paměti ve vlastním (tj. topografickém) smyslu slova. W: Kolektivní pamět'. Red. N. Maslowski, J. Šubrt. Praha: Karolinum, s. $141-154$.

Pomian, K. (2006). Historia wobec pamięci. Lublin: Wydawnictwo Uniwersytetu Marii Curie-Skłodowskiej.

Rydiger, M. (2013). Terytoria pamięci w sztuce wspótczesnej. W: Pamięć. Rejestry i terytoria. Red. P. Orłowska. Kraków: Międzynarodowe Centrum Kultury, s. 57-65.

Saryusz-Wolska, M., Traba, R. (2014). Modi memorandi. Leksykon kultury pamięci. Warszawa: Wydawnictwo Naukowe Scholar.

Schacter, D. L. (2003). Siedem grzechów pamięci. Przeł. E. Haman. Warszawa: Państwowy Instytut Wydawniczy.

Součková, M. (1995). Neznámý člověk. Praha: Český spisovatel.

Součková, M. (2018). Élenty. Dopisy př́telům 1942-1982. Praha: Prostor.

Weinrich, H. (2018). Przechowane, czyli zapomniane. Przeł. P. Majewski. W: Antropologia pamięci. Zagadnienia i wybór tekstów. Red. P. Majewski, M. Napiórkowski. Warszawa: Wydawnictwo Uniwersytetu Warszawskiego, s. 313-325. https://doi. org/10.31338/uw.9788323533627.pp.313-325.

Wójcicka, M. (2014). Pamięć zbiorowa a tekst ustny. Lublin: Wydawnictwo Uniwersytetu Marii Curie-Skłodowskiej.

Wójcicka, M. (2018). Język pamięci zbiorowej (w kontekście kultury oralności, piśmienności i elektralności). Prolegomena. W: Pamięć w ujęciu lingwistycznym. Zagadnienia teoretyczne i metodyczne. Red. W. Czachur. Warszawa: Wydawnictwa Uniwersytetu Warszawskiego, s. 68-93. https://doi.org/10.31338/uw.9788323 530077.pp.68-93.

Zaleski, M. (2004). Formy Pamięci. Gdańsk: słowo/obraz terytoria. 